DOI: $10.19195 / 2084-5065.52 .9$

\title{
How much reasonableness is there in the standard of a reasonable man? A few remarks regarding a reasonable man in Polish criminal law*
}

\author{
SZYMON TARAPATA \\ ORCID: 0000-0002-4095-8892 \\ Department of Criminal Executive Law, Department of Criminal Law, \\ Faculty of Law and Administration, Jagiellonian University, Poland
}

In Polish criminal law certain standards are regularly applied. ${ }^{1}$ These interpretational tools are often used in the process of attribution of criminal liability. At least a few basic kinds of such personal models can be distinguished. There are: 1) reconstructive and 2) constructive (normative) standards. ${ }^{2}$ The first model serves as an answer to the question as to what is, whereas the second one says what ought to be. The reconstructive standard is employed to find certain facts of a criminal case (e.g. determining if a perpetrator's act was committed intentionally). The primary aim

* This article is a result of research which has been done as part of the FUGA-5 grant entitled "Model of attribution of perpetration in Polish criminal law," conducted on the basis of application no. 2016/20/S/HS5/00549 and funded by The National Centre of Science. The theorems contained in the text were also presented in a monograph: S. Tarapata, Przypisanie skutku w sensie dynamicznym w polskim prawie karnym, Kraków 2019.

1 See: M. Rodzynkiewicz, Modelowanie pojęć w prawie karnym, Kraków 1998, pp. 9-25.

2 See: K. Lipiński, Wzorce osobowe w prawie karnym, Wrocław 2018, [unpublished doctoral dissertation], pp. 15-24. 
of the constructive model is to formulate criteria which should be met in order to attribute criminal liability. ${ }^{3}$

In Polish criminal law two opposing tendencies are observed. The first one is generalisation, whereas the second one is individualisation of penal liability. ${ }^{4}$ In short, generalisation is a tendency to concentrate on those elements of the perpetrator's act that are universal and typical for his cohort. Individualisation, on the other hand, basically focuses on features typical of a certain perpetrator. Due to these tendencies a general model is often applied in the process of criminal evaluation. In some situations, however, lawyers individualise it to a greater or lesser extent. Sometimes it seems to be essential to assume that a model should have a particular person's features. In some cases it is necessary to use a totally individual standard (when only one living person among the members of the population meets certain criteria).

The general standard is objective, while the individual one is rather subjective. When the standard is objective, it concentrates on external features of the criminal act independent of its psychological aspects. In turn, subjective standard refers to the perpetrator's psychological attitude toward his conduct. However, the individual standard should not be subjective since in some cases this kind of model would not refer to the perpetrator's state of mind. Therefore, not everything that is individual can also be subjective (e.g. when perpetrator's legs are paralysed, paralysis is an individual rather than subjective feature).

One of the personal models which are permanently used in criminal law is undoubtedly the standard of a reasonable man (it is also called a model/good citizen, prudent person, reasonable person etc.). ${ }^{5}$ This tool was not defined in the Polish criminal code. The term, however, is regularly used among scholars, in the literature and by the judiciary. ${ }^{6}$ The aim

3 J. Giezek, P. Kardas, "O kryteriach obiektywnego oraz subiektywnego przypisania z perspektywy podstaw odpowiedzialności karnej — uwagi wprowadzające,” [in:] Obiektywne oraz subiektywne przypisanie odpowiedzialności karnej, ed. J. Giezek, P. Kardas, Warszawa 2016, pp. 16-17.

4 K. Lipiński, op. cit., p. 52.

5 S. Tarapata, op. cit., pp. 143-163. See also: W. Wróbel, A. Zoll, Polskie prawo karne. Część ogólna, Kraków 2013, p. 221.

6 P. Zakrzewski, Stopniowanie winy w prawie karnym, Warszawa 2016, pp. 281-283; judgement of the Supreme Court of 30th October 2013, II KK 130/30, LEX no. 1396511. 
of this report is to present the role of this standard in the criminal liability attribution process.

It is important to shortly determine how the word "reasonable" should be understood. Generally speaking, a man is reasonable when he efficiently uses all available instruments so as to achieve a certain aim. In criminal law this aim is to assure maximum possible protection of legal interests, which are the values protected by the legislator. What is important is that the state accepts some level of risk to legal interests. Otherwise, people might feel a chilling effect which would paralyse social life. ${ }^{7}$ That is why the legislator allows us to drive a car, play football or even fight in a boxing ring. In conclusion, the reasonable man should take his actions without exceeding the limits of acceptable peril to protected values and at the same time doing his best to salvage these interests when such danger occurs or might occur. ${ }^{8}$

The matter of extreme importance to criminal law is the answer to the following questions:

1. What circumstances are important for criminal evaluation of the perpetrator's act?;

2. Should a reasonable man be equipped only with general or individual or psychological features of the certain perpetrator as well and if so, which of these? ${ }^{9}$

In Polish criminal law a perpetrator can be criminally liable for a crime (felony or misdemeanour), if an unlawful, punishable, wrongful and culpable act or omission was perpetrated (unlawfulness, punishability, wrongfulness, culpability are the essential elements of crime). ${ }^{10}$ A reasonable man standard plays the most important role in establishing unlawfulness. It should be necessarily reminded that an act or omission is unlawful when it is contrary to the legal norm (conduct norm). ${ }^{11}$ A certain act

7 A. Zoll, "O normie z punktu widzenia prawa karnego," Krakowskie Studia Prawnicze 23, 1990, pp. 79-80.

8 S. Tarapata, op. cit., pp. 154-155.

9 Ibid., pp. 159-160.

10 See: S. Tarapata, Dobro prawne w strukturze przestepstwa. Analiza teoretyczna i dogmatyczna, Warszawa 2016, pp. 169-183.

11 More information regarding conduct norms: M. Dąbrowska-Kardas, Analiza dyrektywalna przepisów części ogólnej kodeksu karnego, Warszawa 2012, pp. 133-138. 
is unlawful when one is disobedient to the rule which would be followed by a reasonable man. The reasonable man figure is helpful in clarifying the content of such essential elements of unlawfulness as: 1) feasibility, 2) foreseeability; 3) rules of prudent conduct. ${ }^{12}$ What is important is that all of these elements are based on social assessments. The assessments are a product of moral rules and universal values which are adopted by society. ${ }^{13}$ In fact, these rules and values should be retrieved and accepted by a judge ruling in the criminal case. Judges have a certain discretion to decide upon these matters. ${ }^{14}$ Consequently, in the process of making these assessments, the sensibility of judges plays an extremely important role. In other words, "in judges we trust."

As already mentioned, a few requirements must be met in order to state that a conduct norm was infringed. It should be strongly emphasised that one's act cannot be deemed as illegal if it were not possible to carry out the order embodied in the norm. In the democratic state of law it is obvious that impossible acts should not be required (impossibilium nulla obligatio est). ${ }^{15}$ This is the reason why the first requirement of unlawfulness which should be met so as to attribute criminal liability is the feature of feasibility (possibility) of lawful behaviour.

Nevertheless, feasibility (possibility) is a relative feature. ${ }^{16}$ A certain act can be feasible for one person and unfeasible for another. Performing a surgical operation is possible for a properly qualified surgeon, whereas an average man in the street is unable to carry it out. Moreover, representatives of certain professions often would have different possibilities. A result can be achieved by the physician working in a well-equipped clinic but the same achievement is impossible for a doctor working in a poorly-equipped hospital situated in a small village. Average people can also have different capabilities. It is the natural consequence of the fact that they differ from each other. Moreover, carrying out a task is possible in

12 S. Tarapata, Przypisanie..., p. 158.

13 A. Zoll, op. cit., p. 78.

14 J. Kochanowski, "Standard 'rozsądnego człowieka' w prawie karnym," Studia Iuridica 20, 1991, p. 134.

15 J. Majewski, Prawnokarne przypisanie skutku przy zaniechaniu (zagadnienia węzłowe), Kraków 1997, pp. 68-70.

16 S. Tarapata, Przypisanie..., p. 166. 
one set of circumstances but performing the same task is not possible in other situations. For example, one may be able to rescue a drowning tourist if he can swim but such conduct is impossible for a person who has no swimming skills. In many situations when it is necessary to evaluate if obedience to the norm was possible, the standard of a reasonable man should be applied.

Due to the fact that people differ, their similar behaviours cannot always be evaluated in the same manner. Otherwise criminal evaluation of these acts would not be just and as such could be questioned under the constitutional rule of equality before the law. ${ }^{17}$ It is not possible to expect the same from everyone. Taking this argument into consideration, the question regarding features which a reasonable man should have seems to be more perplexed. One of the main problems for such an evaluation is to decide which facts should be taken into consideration while determining how a reasonable man would behave in a certain situation. The question must arise how this dilemma is to be solved.

Achieving a particular result:

1. may be impossible for any person (so called absolute impossibility);

2. may be possible for everyone;

3. may be possible only for a group of people equipped with certain tools, appropriate knowledge or special skills;

4. may be possible only for a single person possessing specific knowledge, skills or a specialised tool;

5. may be generally possible but impossible for a specific candidate for the perpetrator.

It has to be considered how the standard of a reasonable man would work in the situations mentioned above. ${ }^{18}$

It is obvious that if something is impossible to achieve, it should not be required by a legislator. For example, it is senseless to expect that one would get to Mars by foot or touch the Sun. ${ }^{19}$ Therefore, lawyers interpreting legal provisions should assume that the legislator is reasonable and does not direct such unreasonable requirements towards citizens.

17 Ibid., pp. 57-58.

18 See more: ibid., pp. 163-187.

19 See also: Z. Ziembiński, Analiza pojęcia czynu, Warszawa 1972, p. 54. 
The second group of situations indicated above is unambiguous. If something is possible for everyone, it is also feasible for a reasonable man. In these kinds of examples a feasibility feature is certainly met.

Evaluation of the third group of situations is ambiguous and depends on the particular social context of one's act or omission. When a mother is unable to rescue her dying son because she does not possess the requisite medical knowledge, her not doing so would not be unlawful. Taking into consideration social assessments serving giving medical assistance in a professional manner should not be reasonably expected from her. The standard of an average reasonable man should be applied rather than the standard of average doctor in such circumstances. ${ }^{20}$

Other conclusions should be expressed when a potential perpetrator is a physician. In such situations if giving medical aid might be possible by an average doctor, the feasibility requirement is fulfilled. ${ }^{21}$ There are, however, some exceptions, e.g. it is worth referring to a situation in which there is a necessity to avert danger to a patient's life by performing the surgical operation but it cannot be carried out because the director of the hospital has not purchased the necessary equipment. This fact should be taken into account while applying the standard of a reasonable man. In such a situation we should use the standard of a reasonable doctor for whom the necessary equipment is unavailable and consequently cannot be used.

On the other hand, if a physician does not have the necessary device while performing an operation because he forgot to equip himself with a lancet, he might not be able to avoid criminal liability. ${ }^{22}$ In such situations the doctor should abide by the standards of a reasonable physician. Such a physician is supposed to perform the operation having at least the right equipment. We claim so because if someone is a professional he should do all that is necessary to be well-prepared to carry out all his duties respecting the principals of medical practice. Consequently, a reasonable man figure is also important in evaluating all behaviours which were performed before the moment a potential perpetrator was obliged to carry out the certain act. When this evaluation is negative, it would be possible to state that — while committing a subsequent omission — one

20 S. Tarapata, Przypisanie..., p. 160.

21 Ibid., pp. 160-161.

22 W. Wróbel, A. Zoll, op. cit., p. 205. 
does not abide by the expected standards of conduct which consequently might give reasons to attribute unlawfulness.

Referring to the fourth group of situations, their assessment depends on the perpetrator possessing extra knowledge, skills or special tools. When he does not meet those characteristics, the feasibility feature would not be met. A legislator should not require the performing of acts which can be carried out only by an above-average gifted person. In such situations an average reasonable man (an average reasonable entrepreneur, physician, nurse, teacher etc.) standard must be applied. It is naturally assumed that legal norms cannot require us to do extraordinary things.

If a potential perpetrator has unique knowledge, skills or special tools, a very important question may arise about the level of requirements which can be imposed on him. In other words, the issue to be resolved is to determine what kind of a reasonable man standard should be applied in such situations. It is purposeful since - as already stated - that legal norms should not require extraordinary things to be done. On the other hand, there are some exceptions to this rule. Strictly speaking, when a potential perpetrator has superior knowledge, skills or special tools which allow him to perform a certain act by using these powers, such behaviour is obviously possible to be carried out. This is the reason why this kind of behaviours can be required by the legislator. This conclusion is extremely important for the content of a reasonable man standard. If a man is reasonable, he would necessarily use all available instruments in order to avert danger to legal interests. On the other hand, if a potential perpetrator does not do his best while providing help, it is not actually possible to claim that this kind of omission is rational. It seems to be obvious that when a patient goes to the above-average gifted doctor, he expects that the doctor shall use his best knowledge and superior abilities whilst delivering medical aid. It is a kind of behaviour which could be rationally expected. In conclusion, in almost all situations when a potential perpetrator has better possibilities to perform, it has to be stated that he should act as a reasonable man and use all his powers so as to achieve an expected goal. ${ }^{23}$ For example, if a driver has a better brake assist system in his car than other drivers have,

23 More: S. Tarapata, Przypisanie..., pp. 214-234. 
he should use it in a hazardous situation in order to limit the danger to the legal interest. If he does not do so, his omission may be found illegal.

Finally, when performing an act which is generally possible but turned out to be unfeasible for a potential perpetrator, the feasibility feature is fulfilled. In such situations the legislator expects abiding by the standards of an average "man on the street." It seems to be obvious that there are some minimal expectations which a citizen living in a society should meet. Meeting these requirements is generally not too difficult for members of society. Therefore, the legislator can reasonably require their fulfilment from everyone. However, there are some exceptions to this rule. If individual impossibility is justified, the legislator cannot require the carrying out of acts which can be performed by an average reasonable man. For example, if a person is paralysed and incapable of walking, such a citizen should not be expected to rescue people who are stuck at the top of a high mountain.

The next feature of unlawfulness is foreseeability. This criterion is mentioned in the Polish Criminal Code. Section 9 paragraph 2 C.C. states that "A prohibited act is committed unintentionally if the perpetrator, without having intent of its commission, commits it due to non-compliance with carefulness required in the given circumstances, although he has foreseen or might have foreseen the possibility of its commission." Despite the fact that this provision gives a definition of unintentionality, scholars emphasise that the criterion of foreseeability is also relevant for intentional prohibited acts. Therefore, it is necessary to apply a reasonable man standard so as to check if the feature of foreseeability has been met.

The feature of foreseeability has one particularly important function. It is clear that carrying out a duty is possible if an addressee of the legal norm has an actual possibility to notice that, in the given circumstances, the obligation should be performed. However, when the possibility of committing a prohibited act is unforeseeable, a potential perpetrator has no (or has very little) chance to behave compliably with the legal norm. Thus, the most important aim of the feature of foreseeability is to require solely possible acts to be done. ${ }^{24}$

24 J. Giezek, Przyczynowość oraz przypisanie skutku w prawie karnym, Wrocław 1994, pp. 76-77. 
When a potential perpetrator foresees the possibility of committing a prohibited act, he is capable of obeying the law. Thus, if he is conscious that he might commit a crime, there is no point in checking the fulfilment of the feature of foreseeability. What is important is that if a reasonable man is aware that he might commit a prohibited act, he uses all available possibilities so as not to act unlawfully. If he does not use them in such a way, a reasonable man standard is not abided by. ${ }^{25}$

Fulfilment of the foreseeability feature should be verified when a potential perpetrator is not conscious of the fact that he may commit a prohibited act. ${ }^{26}$ In such situations a lawyer is to employ a reasonable man test. Using this test, it has to be determined what level of consciousness about the given circumstances the potential perpetrator should have had. The level of required awareness depends on the social context in which an act is carried out and the role of the potential perpetrator in society. The crucial role of the test of foreseeability is giving the answer to the question if the reasonable man had been in the perpetrator's shoes, would he have predicted the possibility of committing the prohibited act, e.g. if a young driver suddenly suffers from a heart attack while driving a car and consequently hits a pedestrian, at the moment of making the decision to driveg the vehicle a possibility of bringing about such a consequence was unpredictable (as such an effect is rather unforeseeable for a reasonable man).

It is obvious that a rational legislator cannot require to foresee a fact which is unpredictable for any human being (the legislator must not to require having God's knowledge). ${ }^{27}$ Moreover, in some circumstances it cannot be expected that a certain fact would be foreseen despite the fact that it could have been noticed solely by a certain group of people. If a father does not call a doctor in order to avert danger to his son's life because the danger is unforeseeable for an average man, such non-doing would not be unlawful. However, if a doctor does not recognise a perilous fact which is recognisable by a model physician and consequently he would not help the patient, the infringement of the legal norm might occur. It is caused by

\footnotetext{
25 S. Tarapata, Przypisanie..., pp. 216-218.

26 Ibid., p. 218.

27 Ibid., pp. 224-225.
} 
the fact that doctors are obliged to recognise more than non-professionals taking care of patients are able to recognise.

Scholars claim that when it is necessary to determine whether a certain fact was possible to foresee, usually the standard of the average man, doctor, entrepreneur etc. should be applied. Nevertheless, it is necessary to accept a different conclusion when the potential perpetrator has special knowledge. ${ }^{28}$ In criminal law literature such a person is called "Besserwisser" (is a German word which means: a person who knows better). ${ }^{29}$ Scholars emphasise that if a potential perpetrator has better knowledge, he is expected to use his special information. ${ }^{30}$ They claim so due to making an assumption that a reasonable man uses all available instruments to protect a legal interest and knowledge is a kind of instrument. In conclusion, if a potential perpetrator knows more, a reasonable man standard should be equipped with this knowledge.

It is possible, however, that in some social contexts a person who has special knowledge would not be expected to use this information. The German literature describes the case of a young student of biology who is a waiter in a Chinese restaurant and gives the soup to the client. Nevertheless, he does not notice that a poisonous fruit was put into the soup, whereas such a fact would have been recognisable for any average student of biology. As a result, the client dies. ${ }^{31}$ It is not subject to question that if the student had been observing the contents of the soup, the consequence would not have occurred. Despite this fact the student cannot be liable for the death of the client. A waiter (even if he is a student of biology) cannot be reasonably required to observe carefully all meals that are delivered to restaurant's clients. In such situations a person who has special knowledge is not required to use this information. However, if the waiter did notice that a poisonous fruit was put into the soup, he would

28 See: M. Rodzynkiewicz, op. cit., pp. 110-111.

29 K. Buchała, Bezprawność przestępstw nieumyślnych oraz wyłączajace ją dozwolone ryzyko, Warszawa 1971, p. 218; M. Rodzynkiewicz, op. cit., p. 110.

30 M. Bielski, Obiektywna przypisywalność skutku w prawie karnym, Kraków 2009 [unpublished doctoral dissertation], pp. 214-215; W. Wróbel, A. Zoll, op. cit., pp. 220-221.

31 J. Giezek, “'Przewidywalnośc' jako kryterium przypisania czynu zabronionego a tzw. 'wiedza szczególna' jego sprawcy," [in:] Między nauka a praktyka prawa karnego. Księga Jubileuszowa Profesora Lecha Gardockiego, eds. Z. Jędrzejewski et al., Warszawa 2014, p. 71. 
be required to eliminate a danger to the client. A reasonable man would behave in such a manner. ${ }^{32}$

It should be necessarily mentioned that a feature of foreseeability could be important in some situations when a perpetrator knows that his act is illegal, e.g. the perpetrator causes a small wound on the victim's hand during a robbery. This kind of injury is normally harmless. However, in the given example the victim is a haemophiliac, about which the perpetrator is unaware. In this situation if the death is brought about, such a consequence could not be attributed to the perpetrator. The reason is that haemophilia rarely happens in society. Suffering from this disease is hardly ever taken into consideration when interacting with another human being. That is why such a fact is rather unforeseeable. What is important, in Polish criminal law an assumption is taken into consideration that a citizen should have real the possibility of predicting the legal consequences of his act. He does not have such a possibility if a risk of bringing about the consequence in a typical situation is so low that it is difficult to be expected. This is the reason why in the haemophiliac case, death cannot be attributed to the assaulter. This leads to the conclusion that in Polish criminal law the eggshell rule cannot be followed. People who use violence do not take their victims as they find them (that is why rules presented in the case R. vs Blaue ${ }^{33}$ are not fully accepted in Polish criminal law). Even if they do something which would not be done by a reasonable man, they can be solely liable for the consequences which might be foreseen under such personal standard. ${ }^{34}$

Finally, an act is unlawful when a perpetrator does not follow the rules of conduct required in the given circumstances. ${ }^{35}$ Such rules indicate how a citizen should behave in order to avoid unacceptable danger to the legal interest. Plenty of conduct rules were described in different statutes. However, there are a lot of situations which are not covered by written rules of conduct. In such cases a judge is required to formulate the rule which is appropriate in given circumstances. In doing so, he has to determine how a reasonable man would behave if he was in a particular situation.

\footnotetext{
32 S. Tarapata, Przypisanie..., p. 162.

33 BAILII Citation Number: [1975] EWCA Crim 3, Case No. 4512/C/74.

34 S. Tarapata, Przypisanie..., pp. 230-231.

35 W. Wróbel, A. Zoll, op. cit., pp. 174-177.
} 
It is clear that a lifeguard does not follow conduct rules if he sleeps on the beach while a tourist is drowning. A prudent lifeguard carefully observes his bathing area while on duty. If he does not do so, his omission infringes the rules of conduct and may be found illegal. This conclusion can be accepted despite the fact that the legislator did not describe that a lifeguard is not allowed to sleep on the beach when he is serving his duties in any statute.

To sum up, it has been already been mentioned that the reasonable man standard is applied in order to check fulfilment of the Polish equivalent of negligence. However, this figure is rather not employed in reference to other kinds of mens rea. It is especially noticeable on the basis of intentional acts. It is obvious that if a perpetrator has a will to commit a prohibited act, he usually foresees a possibility of committing such conduct.

Finally, it is necessary to remember that if it is determined that one's act does not comply with the standard of reasonable man, it is not enough to conclude that a potential perpetrator is liable for a crime. It is still necessary to meet other elements of actus reus and structure of crime in order to claim that a citizen is criminally liable for a certain felony or misdemeanour. ${ }^{36}$

\section{References}

Bielski M., Obiektywna przypisywalność skutku w prawie karnym, Kraków 2009 [unpublished doctoral dissertation].

Buchała K., Bezprawność przestępstw nieumyślnych oraz wyłaczające ją dozwolone ryzyko, Warszawa 1971.

Dąbrowska-Kardas M., Analiza dyrektywalna przepisów części ogólnej kodeksu karnego, Warszawa 2012.

Giezek J., “'Przewidywalnośc' jako kryterium przypisania czynu zabronionego a tzw. 'wiedza szczególna' jego sprawcy," [in:] Między nauka a praktyka prawa karnego. Księga Jubileuszowa Profesora Lecha Gardockiego, eds. Z. Jędrzejewski et al., Warszawa 2014.

Giezek J., Przyczynowość oraz przypisanie skutku w prawie karnym, Wrocław 1994.

36 See more: P. Kardas, “O relacjach między strukturą przestępstwa a dekodowanymi z przepisów prawa karnego strukturami normatywnymi," Czasopismo Prawa Karnego i Nauk Penalnych 4, 2012, pp.5-63. 
Giezek J., Kardas P., “O kryteriach obiektywnego oraz subiektywnego przypisania z perspektywy podstaw odpowiedzialności karnej — uwagi wprowadzające,' [in:] Obiektywne oraz subiektywne przypisanie odpowiedzialności karnej, ed. J. Giezek, P. Kardas, Warszawa 2016.

Kardas P., "O relacjach między strukturą przestępstwa a dekodowanymi z przepisów prawa karnego strukturami normatywnymi," Czasopismo Prawa Karnego i Nauk Penalnych 4, 2012.

Kochanowski J., "Standard 'rozsądnego człowieka’ w prawie karnym," Studia Iuridica 20, 1991.

Lipiński K., Wzorce osobowe w prawie karnym, Wrocław 2018 [unpublished doctoral dissertation].

Majewski J., Prawnokarne przypisanie skutku przy zaniechaniu (zagadnienia węzłowe), Kraków 1997.

Rodzynkiewicz M., Modelowanie pojęć w prawie karnym, Kraków 1998.

Tarapata S., Dobro prawne w strukturze przestęstwa. Analiza teoretyczna i dogmatyczna, Warszawa 2016.

Tarapata S., Przypisanie skutku w sensie dynamicznym w polskim prawie karnym, Kraków 2019.

Wróbel W., Zoll A., Polskie prawo karne. Część ogólna, Kraków 2013.

Zakrzewski P., Stopniowanie winy w prawie karnym, Warszawa 2016.

Ziembiński Z., Analiza pojęcia czynu, Warszawa 1972.

Zoll A., "O normie z punktu widzenia prawa karnego," Krakowskie Studia Prawnicze 23, 1990.

\section{Summary}

In this article the author presents how the figure (standard) of a reasonable man (model citizen) is used in Polish criminal law. It was shown that this standard is helpful mainly to determine the scope of unlawfulness adequate in a given situation (limits of the conduct norm). The article also presents what factors are important in the process of applying a reasonable man standard.

Keywords: action, omission, reasonable man, attribution of the consequence, causation, foreseeability 